\title{
BASES BIO-PSICOSSOCIAIS DA COOPERAÇÃO E O PARADIGMA COLABORATIVO NAS POLÍTICAS PÚBLICAS $^{1}$
}

\author{
THE BIO-PSYCHOSOCIAL BASIS OF COOPERATION AND THE \\ COLLABORATIVE PARADIGM IN PUBLIC POLICIES
}

João Pedro Schmidt

\section{Resumo}

0 artigo desenvolve o argumento de que a cooperação é uma característica natural dos seres humanos, resultante da interação entre a dimensão biológica e social no curso evolutivo da nossa espécie. Contrariando o darwinismo social, inúmeros estudos recentes corroboram a abordagem evolucionista inaugurada por Kropotkin do mutualismo como principal fator da evolução humana. Tal abordagem desafia os cânones predominantes ainda hoje no direito, na economia e na política, que oscilam entre o Leviatã e o mercado. Para sustentar a tese da índole cooperativa da nossa espécie são apresentadas evidências de pesquisas da biologia, da neurociência, da psicologia e das ciências sociais sobre as bases bio-psicossociais da cooperação: vínculos sociais, necessidades básicas, empatia e predisposição altruísta. 0 texto desdobra-se em cinco tópicos. Inicialmente são expostas as teses do egoísmo natural e da sociabilidade; em seguida, são explicitados os conceitos de vínculos sociais, necessidades básicas, empatia e altruísmo; depois, as diversas formas de cooperação; e, por derradeiro, indicativos sobre transformações sociopolíticas necessárias à vigência de um paradigma colaborativo em políticas públicas. 0 método é histórico-crítico e a técnica de pesquisa é bibliográfica.

Palavras-chave: Cooperação. Egoísmo. Paradigma colaborativo. Políticas públicas. 


\section{ABSTRACT}

The article develops the argument that cooperation is a natural trait of human beings that accompanies the long process of evolution of our species, resulting from the interaction between the biological and social dimension. Contrary to social Darwinism, numerous recent studies corroborate Kropotkin's evolutionist approach that mutualism is the main factor in human evolution. Such an approach challenges the canons still prevailing in law, economics and politics, which oscillate between Leviathan and the market. To support the thesis of the cooperative nature of our species, the text presents evidence from researches in biology, neuroscience, psychology and social sciences on the bio-psychosocial bases of cooperation: social bonds, basic needs, empathy and altruistic predisposition. The text unfolds in five topics. Initially the theses of natural egoism and sociability are exposed; then the concepts of social bonds, basic needs, empathy and altruism are explained; then the various forms of cooperation; and, lastly, indicative of sociopolitical transformations necessary for give effect of a collaborative paradigm in public policies. The method is historical-critical and the research technique is bibliographical.

Keywords: Cooperation. Egoism. Collaborative paradigm. Public policies.

\section{INTRODUÇÃO}

As ciências sociais vêm desenvolvendo majoritariamente a análise de fenômenos políticos e sociais, incluindo a luta pelos direitos humanos e a cidadania, a partir da tensão entre Estado e mercado. Esses dois polos exercem notável impacto na vida social, mas a ênfase exclusiva nos mesmos leva a análises reducionistas e insuficientes para explicar os comportamentos no interior das redes familiares, comunitárias e da sociedade civil, bem como a economia e a política. Defende-se aqui um ponto de vista não-reducionista: a capacidade de cooperação presente em todos os grupos humanos, ao longo de todo o processo evolutivo da nossa espécie, é muito anterior ao Estado e ao mercado e explica parte importante do comportamento humano.

Cooperação designa o engajamento de pessoas em atividades que visam o benefício mútuo. É sinônimo de colaboração, mutualidade, ajuda mútua, reciprocidade e solidariedade, termos que reportam a compor- 
tamentos em que os cooperantes agem visando benefícios mútuos. 0 altruísmo, frequentemente equiparado à cooperação, é um fenômeno distinto: trata-se da ajuda a outro sem expectativa de retribuição.

Os benefícios da cooperação vêm sendo reconhecidos ao longo dos tempos: várias pessoas agindo juntas alcançam maiores e melhores resultados do que agindo separadas; tarefas complexas só são viáveis mediante ação conjunta; organizações e instituições dependem do agir coordenado de muitos. Historicamente, a força da cooperação foi enaltecida nos levantes de classes e povos oprimidos, no movimento operário, sindical e cooperativista, em teorias revolucionárias como o marxismo e o anarquismo, no cristianismo primitivo e outras expressões religiosas. Estudiosos de diversas vertentes do pensamento atual endossam o ponto de vista de que a cooperação é uma capacidade natural dos humanos, incluindo pensadores comunitaristas, teóricos do capital social, da sociedade civil, do terceiro setor, dos bens comuns, da economia social, do cooperativismo, entre outros.

Nas últimas décadas impôs-se o ponto de vista oposto, o do egoísmo natural de nossa espécie. Em tempos de agudos conflitos, guerras, litigiosidades, desigualdades econômico-sociais impressionantes e comportamentos individualistas, a noção de que os seres humanos têm índole cooperativa é recebida com descrédito em muitos ambientes e combatida ferozmente pelos arautos do liberalismo econômico. A tese do egoísmo natural encontra respaldo no pensamento ocidental em duas tradições distintas: a tradição do Leviatã (Hobbes) e a da mão invisível (Adam Smith). A primeira conduz à ênfase no controle estatal e burocrático dos antagonismos sociais; a segunda confia que, livres de controles, os vícios privados resultam em benefícios públicos. Essas concepções distintas se expressam na análise de políticas públicas na oscilação pendular entre a intervenção estatal e a privatização. Uma e outra desconsideram a vocação colaborativa dos seres humanos como fundamento da ação coletiva.

Invocar a natureza humana em favor de uma ou outra tese não é uma questão menor. Todas as ordens sociais ao longo da história foram justificadas em nome da natureza ou de alguma divindade, derivando daí a sua força legitimadora. A natureza humana ${ }^{2}$ é um tema clássico da filosofia e das ciências, não sendo escopo do presente texto rememorar a extensa pro- 
dução atinente. Pretende-se, sim, destacar evidências de recentes estudos da biologia, da psicologia evolutiva, da neurociência e das ciências sociais em favor da tese da nossa propensão natural à cooperação, sem negar a tensão permanente entre impulsos colaborativos e egoístas.

0 problema que conduz o presente artigo é: quais são as bases bio-psicossociais da cooperação e qual a influência que podem exercer na conformação de um paradigma colaborativo nas políticas públicas? A resposta ao problema é construída a partir de pesquisa bibliográfica, em que se mostra a maior robustez dos argumentos em favor da índole cooperativa dos humanos e se elenca as bases fundamentais que a expressam, no entrelaçamento da dimensão biológica e social.

0 texto desdobra-se em cinco momentos. Inicialmente são apresentadas as teses do egoísmo natural e da sociabilidade dos humanos; em seguida, são explicitadas as bases bio-psicossociais da cooperação; depois, as variadas formas de cooperação nas diferentes esferas sociais; e, por derradeiro, as transformações culturais e institucionais necessárias à construção e hegemonia do paradigma colaborativo em políticas públicas.

\section{A TESE DO EGOÍSMO E DA CONFLITIVIDADE NATURAL DOS HUMANOS}

Na seara filosófica, a formulação inicial da tese do egoísmo natural foi feita pelo filósofo Thomas Hobbes. Na obra Leviatãa de 1651, Hobbes desenvolve a concepção de que originariamente os homens viviam em estado de natureza, onde grassavam a liberdade individual, o egoísmo e os conflitos. Na condição original de medo contínuo e perigo de morte violenta, a vida humana era "solitária, pobre, sórdida, embrutecida e curta", vaticina Hobbes (1997, p. 109), contrária a qualquer progresso material e avanço nas ciências e artes. Os conflitos entre os homens derivam das paixões próprias à sua natureza. Há três causas principais de discórdia: competição, desconfiança e glória. A primeira leva os homens a atacar os outros em vista do lucro, a segunda em vista da segurança e a terceira em vista da reputação. Na ausência de um poder comum, impõe-se a guerra de todos contra todos. $\mathrm{O}$ estado de natureza é um estado de anomia, no 
qual as noções de bem e de mal, de justiça e injustiça, não têm lugar; não há propriedade, nem distinção entre o meu e o teu; roubar e espoliar uns aos outros é usual. Nessa condição, "só pertence a cada homem aquilo que ele é capaz de conseguir, e apenas enquanto for capaz de conservá-lo". (HOBBES, 1997, p. 110)

A aspiração por uma vida mais segura e mais satisfatória criou as condições para o surgimento do Estado, um poder comum, mediante um pacto de união (contrato social). Perde-se a liberdade em troca de segurança e melhores condições de vida. Esse contrato social é um pacto de cada um com todos, "como se cada homem dissesse a cada homem: cedo e transfiro meu direito de governar-me a mim mesmo a este homem, ou a esta assembleia de homens, com a condição de transferires a ele teu direito, autorizando de maneira semelhante todas as suas ações". (HOBBES, 1997, p. 144) O Estado-Leviatã é um poder soberano, fonte de todos os direitos e faculdades dos cidadãos. É remédio para a natureza corrompida dos homens, uma "disciplina das paixões", as quais predispõem os homens à insociabilidade, aos prazeres sensuais, à preguiça, à vanglória, à vaidade e à competição. A criação do Estado através de um pacto de união não é um fato natural: é um ato racional e da vontade humana, em nome da paz e da segurança. A política é um embate contra a emoção. (BOBBIO, 1991)

Estado de natureza e contrato social são expedientes teóricos, construtos ficcionais para justificar a necessidade do Estado sem recorrer a argumentos religiosos. Hobbes não apresenta a narrativa histórica que muitos imaginam - a de uma didática divisão da história humana em dois momentos cronológicos: antes do contrato social, nas sociedades primitivas, vigeu o estado de natureza; a partir do contrato social, surgiu o Estado e a civilização. Mas, a leitura derivada de sua obra originou um senso comum em torno dessa suposta divisão cronológica, que é completamente inverossímil à luz dos estudos antropológicos, arqueológicos, sociológicos e históricos. As sociedades primitivas, longe da "guerra de todos contra todos" e do "homem, lobo do próprio homem", eram complexas teias de relações, hierarquias e alianças, em que, como hoje, competição e cooperação andavam lado a lado. 
Na economia, a tese do egoísmo natural foi assentada por Adam Smith, mas, diferente de Hobbes, numa perspectiva anti-estatal. Em $A$ Riqueza das Nações, de 1776, Smith defendeu a nascente economia de mercado capitalista e as vantagens do livre mercado com base na premissa de que o auto-interesse é a mola propulsora adequada da economia e do bem-estar social. Numa economia de mercado, as trocas entre produtores e consumidores não são regidas pela benevolência e sim pelo interesse. Cada indivíduo busca empregar seu capital de forma que seu produto tenha o máximo valor possível, visando apenas o seu próprio ganho, sem buscar e sem saber se está promovendo o interesse público. "Não é da benevolência do açougueiro, do cervejeiro ou do padeiro que esperamos nosso jantar, mas da consideração que eles têm pelo seu próprio interesse", argumenta Smith (1996, p. 74). A anarquia do mercado (ausência de poder central), longe de ser um defeito, é benéfica para a sociedade: ao visar seu próprio interesse, cada qual "é levado como que por mão invisível a promover um objetivo que não fazia parte de suas intenções", de modo que pensando em si "o indivíduo muitas vezes promove o interesse da sociedade muito mais eficazmente do que quando tenciona realmente promovê-lo." (SMITH, 1996, p. 438)

A obra de Smith deu consistência à crença liberal nas virtudes do egoísmo (sendo pouco conhecidas suas observações sobre a importância da empatia em A Teoria dos Sentimentos Morais), crença sintetizada por Bernard de Mandelville no adágio dos "vícios privados, benefícios públicos". Segundo esse ponto de vista, o interesse próprio é o guia mais seguro para o alcance do progresso e do bem comum, muito mais do que as leis e o Estado. Os malefícios da intervenção estatal e as vantagens do auto-interesse e do livre mercado passaram a ser as premissas centrais do liberalismo econômico.

O pensamento liberal incorporou a tese utilitarista de Jeremy Bentham de que o comportamento humano é regido pela busca do prazer e fuga da dor: "A natureza colocou o gênero humano sob o domínio de dois senhores soberanos: o prazer e a dor. Somente a eles compete apontar o que devemos fazer, bem como determinar o que na realidade faremos." (BENTHAM, 1984, p. 9) A busca incessante do auto-interesse visando maximizar o prazer e fugir da dor é a essência do conceito li- 
beral do homo economicus, que transbordou da ciência econômica para as ciências sociais por meio da teoria da escolha racional (ou teoria da escolha pública). Na ciência política, teóricos alinhados a essa perspectiva explicam o comportamento de governos, partidos e cidadãos com base na racionalidade calculista, egoísta, de perdas e ganhos, e a democracia é reduzida a um processo competitivo de seleção das elites pelo voto, similar à competição do mercado. Um de seus mais conhecidos porta-vozes, Anthony Downs (1999, p. 49), afirma que, embora não se deva deixar de reconhecer que há comportamentos altruístas na política, "aceitamos o axioma do interesse pessoal como uma pedra angular da nossa análise".

Na biologia, a teoria da evolução de Charles Darwin tornou-se a principal trincheira teórica do egoísmo natural. No clássico A Origem das Espécies, de 1859, Darwin expõe as bases da teoria da evolução, afirmando que a origem, a diversidade, a perpetuação e as mutações das espécies não se devem a nenhuma força externa e sim à seleção natural. A seleção natural consiste fundamentalmente na "preservação das diferenças e das variações favoráveis aos indivíduos, e destruição das prejudiciais". (DARWIN, 2009, p. 86) Metaforicamente, a seleção natural trabalha todos os dias do ano em todo o mundo "analisando" as variações, rejeitando as que são nocivas, conservando e acumulando as que são benéficas. Trabalha em silêncio para melhorar cada ser vivo na relação com as suas condições de vida. Só percebemos essas lentas alterações com o passar dos tempos, mas a nossa capacidade de percebê-las é muito limitada, de modo que apenas conseguimos vislumbrar que as formas de vida agora são diferentes do que foram outrora. Cada organismo individual batalha pela vida, luta pela sua sobrevivência e pela sobrevivência da prole. Os organismos mais bem adaptados ao meio têm maiores chances de sobreviver, são, portanto, selecionados para aquele ambiente. Os genes dos organismos selecionados passam a predominar nas gerações futuras.

A sobrevivência dos mais aptos tornou-se o jargão central do darwinismo social, teoria popularizada por Herbert Spencer, que impulsionou enfoques racistas, xenófobos e discriminatórios. Tal enfoque atribuiu a Darwin a tese de que todas as energias vitais do indivíduo estão a serviço da luta incessante por sua própria sobrevivência, o que o leva a sacrificar tudo o que a ameace. As posições de Darwin são, todavia, 
mais nuançadas. Junto com a luta pela própria sobrevivência está a luta pela sobrevivência da prole. Segundo Batson (2011, p. 233), o impulso vital em favor da sobrevivência da prole é a base genética do altruísmo.

Na psicologia, a naturalização do egoísmo recebeu suporte nas obras de Sigmund Freud. 0 criador da psicanálise difundiu uma imagem bastante sombria do ser humano, cujos traços negativos se manifestariam desde a primeira infância. (RICARD, 2015; RIFKIN, 2010; KRZNARIC, 2015) Para Freud, a criança é egoísta e aspira à satisfação de suas necessidades, sem consideração a outras crianças. Na busca constante do prazer e da fuga da dor revela-se o egoísmo como um traço comum à humanidade: os outros só têm importância para o indivíduo à medida que favorecem a satisfação de suas necessidades. 0 homem está dividido entre Eros, a pulsão sexual de preservação da vida, e Thanatos, a pulsão de morte, que primeiro volta-se contra o próprio indivíduo para então voltar-se contra os outros. Tanto nos animais como nos humanos a tendência à agressão é uma pulsão primária e autônoma, um traço indestrutível da natureza humana. 0 ser humano manifesta pouca inclinação para o bem. O comportamento benévolo não é altruísmo verdadeiro, mas "um meio de conter tanto quanto possível as tendências agressivas constantemente à espreita em sua mente". (RICARD, 2015, p. 285)

O sucesso da tese do egoísmo e da conflitividade natural é notável. No Ocidente, tornou-se o ponto de vista predominante no contexto da Guerra Fria, como um elemento da batalha ideológica do capitalismo contra o comunismo, lembra Benkler (2011, p. 17). A índole egoísta e conflitiva da nossa espécie foi parte de um ideário de luta contra a visão cristã medieval, as práticas comunitárias tradicionais, o movimento sindical e operário, o socialismo. Hoje é uma ferramenta de luta contra os movimentos por igualdade social e redistribuição de poder e riqueza. Várias gerações foram formadas sob o predomínio dessa visão simplificadora da realidade humana, que está sendo desafiada tanto pela observação corriqueira da ação humana, reveladora de que grande parte das nossas ações não é nem egoísta nem puramente racional, como por eventos de grande magnitude, como o colapso econômico de 2008/2009, que explicitou a falência dos sistemas econômicos e financeiros baseados no auto-interesse. 


\section{A TESE DA NATUREZA SOCIAL DOS HUMANOS}

Na filosofia moderna, a primeira contraposição ao egoísmo natural veio de Jean-Jacques Rousseau. No Discurso sobre a Origem e os Fundamentos da Desigualdade entre os Homens, de 1754, o filósofo apresenta o conhecido argumento de que o homem nasce bom, mas a sociedade o corrompe. Na forma natural de vida os humanos tinham poucas necessidades, facilmente satisfeitas. Esse estado natural foi "o mais propício à paz e o mais conveniente ao gênero humano", um período sem desigualdades, com paz e com liberdade, diz Rousseau (1983, p. 252). Mas, para ele os humanos não são naturalmente propensos à vida social, e encontram-se na civilização e na propriedade privada os fatores que tornaram os homens gananciosos, mesquinhos, avarentos e invejosos. "O verdadeiro fundador da sociedade civil foi o primeiro que, tendo cercado um terreno, lembrou-se de dizer isto é meu e encontrou pessoas suficientemente simples para acreditá-lo." (ROUSSEAU, 1983, p. 259) Embora compartilhe da noção do indivíduo fragmentado e da sociedade como um mero agregado de indivíduos, Rousseau antecipou em alguns séculos argumentos importantes acerca dos sentimentos de vinculação social, como a compaixão, generosidade, clemência, piedade e os riscos da razão egoísta.

A reflexão filosófica e sociológica sobre a natureza humana deu um salto importante com a obra de Karl Marx, com sua ênfase no condicionamento social dos fenômenos humanos. $\mathrm{O}$ que era visto como natural passou a ser designado como fruto de relações sociais e históricas. Para Marx, os humanos são seres que trabalham e pelo trabalho transformam a natureza e se (re)criam constantemente a si mesmos. Não há uma essência humana separada que explique as relações sociais: a essência humana "em sua efetividade é o conjunto das relações sociais", diz Marx (1978 p. 52) na sexta das Teses sobre Feuerbach. Não são as características individuais que explicam as relações sociais; é o contrário: essas características são explicáveis à luz de relações sociais concretas. Com variações ao longo de sua complexa obra, a abordagem marxiana do tema da natureza humana sempre se manteve em torno dos conceitos de trabalho e de práxis. 0 homem é essencialmente um ser produtor, 
cuja práxis (ação de transformação visando uma finalidade planejada) é compreensível à luz de relações de produção sociais e históricas. No capitalismo, a potência criadora do trabalho não se manifesta em razão da divisão entre o produtor e os meios de produção, situação real que produz o trabalho alienado, que leva o trabalhador a não se reconhecer no mundo que ele mesmo produz, nem se reconhece a si mesmo como agente de transformação. A potência criadora do trabalho só poderá se expressar plenamente numa sociedade sem classes sociais, em que os trabalhadores forem os donos dos meios de produção e determinarem as condições da produção.

Quanto à cooperação, é um fenômeno histórico, afirma Marx, que não deriva de alguma essência humana abstrata, e sim está relacionada às condições sociais de produção. Em um capítulo dedicado ao assunto, em $O$ Capital, de 1867, a cooperação é definida como "a forma de trabalho em que muitos trabalham lado a lado e conjuntamente, num mesmo processo de produção ou em processos de produção diferentes, mas conexos". (MARX, 1983, p. 259) A fusão de forças individuais numa força global eleva a potência do trabalho, pois o contato social provoca emulação e excitação dos espíritos vitais, que elevam a capacidade de rendimento. 0 trabalho cooperativo permite estender a escala espacial de ação ao mesmo tempo que estreita o campo espacial de produção, mobiliza em pouco tempo muito trabalho em momento crítico, imprime continuidade ao movimento de muitos trabalhadores atuando simultaneamente. "Ao cooperar com outros de um modo planejado, o trabalhador se desfaz de suas limitações individuais e desenvolve a capacidade de sua espécie", conclui Marx (1983, p. 262) No modo de produção capitalista, a cooperação serve aos interesses do capital, é a força produtiva social do capital. 0 capital contrata, dirige, controla e lucra com a atividade cooperada de trabalhadores: "1 dúzia de pessoas juntas, numa jornada simultânea de 144 horas, proporciona um produto global muito maior do que 12 trabalhadores isolados, cada um dos quais trabalha 12 horas, ou do que 1 trabalhador que trabalhe 12 dias consecutivos" (MARX, 1983, p. 260). 0 capital alimenta-se da cooperação; desde o início do processo, é o trabalho cooperado e não o trabalho isolado que constitui a base do modo de produção capitalista. 
A teoria marxiana trouxe contribuições duradouras. Desnaturalizou o comportamento egoísta, vinculando-o a fatores sociais próprios dos antagonismos existentes das sociedades de classes, e vinculou a cooperação às condições concretas do trabalho. Nessa lógica, a cooperação não necessariamente converge para o bem comum; muitas vezes é utilizada em prol de interesses de classe. Por outro lado, ao sustentar a concepção de que tudo o que é humano é condicionado social e historicamente, deixou em aberto uma série de interrogações relativas à herança biológica. Haveria ou não influência de fatores genéticos estabelecidos ao longo do processo de evolução sobre o comportamento humano?

Os estudos do naturalista e escritor russo Piotr Kropotkin, no início do século XX, proporcionaram as bases para suprir tais lacunas mediante a reinterpretação da teoria evolucionista de Darwin. Na obra Ajuda Mútua: um Fator de Evolução, de 1902, Kropotkin (2009, p. 11) conta que ao observar a vida animal nas geladas terras da Sibéria, não verificou nada que confirmasse aquela luta cruel pelos meios de subsistência entre animais da mesma espécie considerada pela maioria dos darwinistas como a característica dominante da luta pela sobrevivência e o principal fator da evolução. Ao contrário, a observação empírica lhe mostrou cenas de ajuda mútua e de ações altruístas ao lado da luta incessante de cada indivíduo pela própria vida. A observação direta da vida de dezenas de espécies de insetos, aves, pássaros e mamíferos lhe mostrou que a vida social é a regra no reino animal, sendo poucas as que gostam do isolamento ou vivem reclusas em pequenas famílias. Kropotkin (2009, p. 22) apresentou um novo ponto de vista, decisivo na história do pensamento evolucionista: "tanto a ajuda mútua quanto a luta de todos contra todos são uma lei da vida animal; mas, enquanto fator de evolução, a primeira tem provavelmente uma importância muito maior", na medida em que "favorece o desenvolvimento dos hábitos e características que asseguram a manutenção e a evolução da espécie, além de maior bem-estar e melhor qualidade de vida para o indivíduo com o menor dispêndio de energia”.

Nas sociedades humanas, segundo Kropotkin, fica particularmente nítido que o apoio mútuo é o fator preponderante da evolução. As primeiras formações sociais humanas foram bandos, tribos ou sociedades semelhantes às sociedades dos mamíferos superiores, evoluindo daí para os 
clãs, com aparição bem mais tarde da família. Os vestígios arqueológicos indicam que o homem primitivo se caracterizou pela forte solidariedade tribal, assentada no direito comum da tribo. Com a aparição das famílias separadas, um importante desenvolvimento cooperativo, existente em todos os continentes, foi a comunidade aldeã, constituída pela união de famílias de descendência comum e que possuíam um certo território em comum. Na Idade Média, a capacidade de cooperação expressou-se exemplarmente nas cidades livres, em que parte da vida pública era definida em assembleias populares, e nas corporações (guildas), caracterizadas pela ajuda fraterna, autoadministração, propriedade comum de bens e deveres sociais. Em alguns locais, as cidades organizaram-se como federações de corporações e de comunidades aldeãs.

O Estado moderno foi forte adversário do mutualismo. Os estados nacionais empenharam-se em eliminar as instituições de cooperação medievais. Só o Estado e a Igreja podiam, por lei, cuidar de assuntos gerais. "A absorção de todas as funções sociais pelo Estado favoreceu necessariamente o desenvolvimento de um individualismo desenfreado e tacanho", entende Kropotkin (2009, p. 181). Todavia, subsistiram por toda parte instituições comunais e por toda parte foram criadas novas formas de cooperação, como sindicatos, associações, cooperativas, sociedades de amigos, clubes, irmandades, institutos, alianças - fato revelador de que os hábitos e costumes de ajuda mútua permanecem plenamente vivos. A essência da psicologia humana continua se revelando no ímpeto da ajuda mútua, nutrido por centenas de milhares de anos.

O novo enfoque evolucionista pode ser resumido na ideia de que a luta pela sobrevivência não é uma batalha de cada indivíduo contra todos, mas de uma massa de organismos contra o ambiente hostil, em que a ajuda mútua é habitual e fundamental para a sobrevivência das espécies. Essa concepção destaca a força do comportamento cooperativo e vem marcando toda uma geração de cientistas da biologia, psicologia evolutiva, neurociência e ciências sociais, como Frans de Waal, Edward Wilson, Michael Nowak, Samuel Bowles, Herbert Gintis, John Cacioppo, Humberto Maturana, Fritjof Capra, Amitai Etzioni, Daniel Batson, Matthieu Ricard, entre outros. A ajuda mútua tornou-se um elemento padrão das teorias evolucionistas modernas. 
A visão clássica do darwinismo levou os biólogos a conceber o processo evolutivo com base em dois princípios: seleção e mutação. 0 biólogo e matemático Michael Nowak (2011) afirma que as investigações científicas conduziram a um terceiro princípio: a cooperação, que é indispensável para entender os aspectos criativos da evolução. A seleção requer a mutação e a cooperação requer seleção e mutação. "Da cooperação pode emergir o lado criativo da evolução, dos genes aos organismos à linguagem e aos comportamentos sociais complexos. A cooperação é o arquiteto mestre da evolução." (NOWAK; HIGHFIELD, 2011, p. 17)

São as espécies sociais que dominam o planeta, assinala Edward Wilson, criador da sociobiologia, em A Conquista Social da Terra, de 2013. Entre os insetos predominam os insetos sociais (formigas, cupins, abelhas); entre os animais de grande porte predomina o homo sapiens. Na lenta evolução humana, algumas adaptações foram notáveis, como o tamanho físico grande e a mobilidade relativa inicial, a especialização dos primatas para viver em árvores, a posterior adaptação para viver em solo (bi-pedalismo), a adaptação dos membros anteriores para a manipulação de objetos, o controle do fogo, a inclusão de carne na dieta alimentar, a reunião de pequenos grupos em acampamentos, a divisão do trabalho. Dispersos inicialmente em pequenos bandos, a reunião de bandos de hominídeos em acampamentos provisórios há pelo menos um milhão de anos foram fundamentais para a coesão e sociabilidade do homo sapiens.

Os evolucionistas não minimizam a força do egoísmo na vida humana. Wilson (2013, p. 72) argumenta que a seleção natural atua em dois níveis: certas forças de seleção agem sobre os traços dos membros individuais e outras agem sobre traços do grupo como um todo. Em termos genéticos, "os alelos (as diferentes formas de cada gene) que favorecem a sobrevivência e a reprodução de cada membro do grupo à custa dos outros estão sempre em conflito com os alelos do mesmo ou de outros genes favorecendo o altruísmo e a coesão". Assim, "egoísmo, covardia e competição atendem ao interesse de alelos individualmente selecionados" e "essas propensões destrutivas são confrontadas por alelos predispondo os indivíduos a comportamentos heroicos e altruístas". Os humanos são o único caso entre mamíferos e vertebrados de domínio da seleção de grupo sobre a seleção individual, mas esse domínio nunca foi e nem será 
completo. A condição humana é "uma confusão endêmica radicada nos processos evolutivos que nos criaram. 0 pior na nossa natureza coexiste com o melhor, e assim sempre será", diz Wilson (2013, p. 75)

O altruísmo - a ajuda a outro sem expectativa de retribuição - é parte do processo de evolução: "o altruísmo autêntico se baseia num instinto biológico pelo bem comum da tribo, posto em marcha pela seleção de grupo, em que grupos de altruístas na época pré-histórica prevaleceram sobre grupos de indivíduos em desordem egoísta”, aponta Wilson (2013, p. 303). Todas as pessoas normais são capazes de ações altruístas. 0 altruísmo não se manifesta apenas nas ações heroicas e de auto-sacrifício, mas em ações cotidianas de pessoas comuns, registra Daniel Batson (2011). Reconhecê-lo não requer que se retorne à tese rousseauniana da benevolência natural. Somos seres marcados pela ambiguidade e ambivalência. Steven Pinker (2013) descreve o emaranhado de impulsos que conduzem a ação humana como o entrelaçamento de demônios interiores (violência predatória, dominância, vingança, sadismo) e anjos bons (empatia, autocontrole, senso moral, razão). 0 que continua sendo objeto de debate entre os autores - e é central nas preocupações deste texto - é a capacidade de criarmos meios efetivos para inibir os demônios interiores e fortalecer os anjos bons da nossa natureza.

Os evolucionistas não propõem um darwinismo social às avessas, como se os genes determinassem a cooperação. 0 comportamento não deriva diretamente dos genes; ele goza de autonomia motivacional, sendo efeito de múltiplos condicionamentos, esclarece Waal (2010). A metáfora do gene egoísta, popularizada por Richard Dawkins, é enganadora porque faz colidir dois níveis que os biólogos se esforçam muito por manter separados: o nível genético e o nível comportamental. (Dawkins alega ter sido mal interpretado, que o egoísmo no nível do gene não equivale ao egoísmo comportamental, mas a escolha do título do livro não permite surpresa quanto à interpretação do público.)

A influência genética é inegável: os genes colocam uma "coleira" em nosso comportamento, mas essa coleira é bem elástica. A revolução cognitiva dos sapiens desencadeada há cerca de 70 milênios, segundo Yuval Harari (2017), assinalou a autonomia da história humana em relação à biologia. A ação humana passou a ser guiada em grande parte 
pelas ficções da realidade imaginada, que possibilitaram a cooperação em grande escala entre pessoas estranhas com base no compartilhamento da mesma crença religiosa ou no pertencimento a uma mesma empresa ou ao mesmo Estado. Os sapiens acreditam coletivamente em coisas que não existem exteriormente e "tais mitos dão aos sapiens a capacidade sem precedentes de cooperar de modo versátil em grande número". (HARARI, 2017, p. 33)

Bowles e Gintis, em Uma Espécie Cooperativa, de 2013, explicam que a trajetória humana é compreensível com base na noção de co-evolução genético-cultural. Há um mútuo condicionamento entre genética e cultura: "preferências e crenças humanas são produtos de uma dinâmica em que genes afetam a evolução cultural e a cultura afeta a evolução genética, ambas fortemente entrelaçadas na evolução de nossa espécie". (BOWLES; GINTIS, 2013, p. 14) E a nossa co-evolução genético-cultural é norteada não pelo gene egoísta e sim pelo gene cooperativo: nas últimas décadas firma-se entre os biólogos a noção de que a cooperação natural é o terceiro princípio fundamental da evolução, ao lado da mutação e da seleção natural. (BENKLER, 2011)

O novo evolucionismo confere extraordinária importância aos vínculos sociais. Um dos fenômenos pelos quais mais claramente se observa a profunda vinculação social que une os indivíduos é o estudo do impacto da solidão. Indivíduos saudáveis estão em convívio com outros e têm vínculos sociais significativos; o isolamento e a falta desses vínculos leva à doença e, em casos extremos, à morte, constatam Cacioppo e Patrick (2010). Estar com os outros e colaborar com os outros não é uma imposição externa, ela responde a profundos impulsos, pré-racionais. A sensação de prazer acompanha o respeito ao comportamento colaborativo, enquanto a repugnância acompanha o comportamento egoísta. Inúmeras pesquisas experimentais atestam que as pessoas "pensam que cooperar é a coisa certa a fazer e têm prazer em fazê-lo, e detestam tratamentos injustos e têm prazer em punir aqueles que violam normas de justiça”, conforme Bowles e Gintis (2013, p. 38). Estudos com uso de scaneamento cerebral comprovam essa interpretação: nos experimentos verifica-se elevada atividade nas áreas do cérebro relacionadas à gratificação na presença de comportamentos cooperativos. 
Outro fenômeno que denota a vinculação social é a empatia, cujo estudo vem modificando cabalmente pressupostos tradicionais da psicologia e concepções sobre a natureza humana. Empatia designa a capacidade de nos colocarmos no lugar do outro, de "andar com os sapatos dos outros", de assumir a perspectiva alheia, comum a todas as pessoas, à exceção de psicopatas e sociopatas (cerca de $2 \%$ a $3 \%$ das pessoas). Waal (2010) sustenta que a empatia, existente em certo grau em outras espécies animais, como chimpanzés e primatas, antes de ser racional é um fenômeno corporal-emocional, expresso no mimetismo e no contágio emocional. Humanos mimetizam o riso, o choro, o bocejo, o sotaque, a dança. Nossos corpos estão preparados para entrar em conexão com outros corpos. Mas, as conexões empáticas nos humanos não são meras reações instintivas, pois estão envolvidas pela racionalidade, pela cultura e pelo ambiente social, que pode favorecê-las ou bloqueá-las.

Na economia, estudos sobre a governança dos bens comuns vieram a respaldar a noção da índole cooperativa dos humanos. Elinor Ostrom, prêmio Nobel de economia de 2009, sistematizou evidências coletadas com base na investigação sobre variadas formas comunais de propriedade e produção de longa duração. Em seu livro O Governo dos Bens Comuns, de 1990, relata diversos casos de sucesso: as terras comuns de Törbel, na Suiça, e das aldeias de Hirano, Nagaike e Yamanoka, no Japão; a irrigação de hortas em Valência, Murcia, Orihuela e Alicante, na Espanha; as comunidades de irrigação nas Filipinas; as bacias de Raymond, Oeste e Central, nos Estados Unidos. Enquanto outras experiências comunais fracassaram, nessas o êxito está associado a observância de princípios como: limites claramente definidos, adequação das regras às condições locais, eleição coletiva, monitoramento, sanções graduadas, mecanismos de resolução de conflitos, respeito ao direito de organização e entidades aninhadas. (OSTROM, 2011, p. 165) Na gestão de bens comuns, os indivíduos frequentemente puseram os interesses da comunidade à frente dos próprios interesses e a preservação de longo prazo à frente das necessidades imediatas de cada pessoa. Ao contrário do que Garrett Hardin previu na tragédia dos comuns, Ostrom mostra que não raro as pessoas se saem bem no cuidado dos bens comuns, melhor que governos ou a iniciativa privada. Para além das vias únicas do Leviatã ou da privatização, 
que dominam a análise de políticas públicas, é preciso incluir, diz ela, a via da autogestão como alternativa à resolução de problemas comuns.

Na sociologia e ciência política são de grande relevância as contribuições trazidas pela teoria do capital social, que aponta a confiança interpessoal como uma das condições fundamentais dos comportamentos cooperativos. Confiar nos outros é condição para colaborar. Em comunidades cívicas, com elevado estoque de capital social positivo, a reciprocidade e o associativismo favorecem a eficácia política e o desenvolvimento econômico. (PUTNAM, 1996)

As teorias da complexidade, como a ecologia profunda, levam a reflexão ainda mais longe. A cooperação humana é entendida à luz de um fenômeno mais amplo: a vida em rede. A compreensão sistêmica, diz Fritjof Capra (2009, p. 93), apoia-se no pressuposto de que "a vida é dotada de uma unidade fundamental, de que os diversos sistemas vivos apresentam padrões de organização semelhantes" que vêm se manifestando ao longo de bilhões de anos de evolução sem solução de continuidade. Em todos os níveis de vida, "os componentes e os processos dos sistemas vivos se interligam em forma de rede", sistemas vivos alojados dentro de outros sistemas vivos, redes dentro de redes. Não há seres vivos isolados: seres vivos estão sempre inseridos em sistemas de vida, sendo cooperação e competição elementos complementares no interior de um sistema vivo. A ciência inspirada no paradigma cartesiano-newtoniano moderno, alega Capra, não capta as profundas conexões da teia da vida. A compreensão dos vínculos que unem os seres vivos requer um novo paradigma científico, que se nutre da perspectiva proporcionada pela física quântica e, no âmbito da biologia, pela ecologia profunda. Tal abordagem amplia o foco da cooperação para além do âmbito social, retomando, em certo sentido, a concepção clássica da vinculação do ser humano à ordem natural, rompida na Idade Moderna.

A nova compreensão da natureza humana traz sólidas razões para substituir a metáfora liberal do homo economicus pelas metáforas do homo sociologicus, homo reciprocans e homo altruisticus, segundo Bowles e Gintis (2013, p. 33). A tese da sociabilidade e cooperação conta ainda com um considerável conjunto de autores e correntes de pensamento, cabendo destacar a doutrina social da Igreja Católica (incluindo a Encí- 
clica Laudato Si, do Papa Francisco (2015)), o pensamento comunitarista (Buber, Taylor, Sandel, Walzer, Etzioni, Bellah, Selznick, Barber, Boswell, Tam) e as teorias do capital social (Putnam, Coleman, Evans, Woolcock, Narayan, Durston, Kliksberg). No principal, convergem na crítica à globalização da sociedade de consumo, ao individualismo e ao modelo de globalização vigente, e trazem aportes à defesa do desenvolvimento sustentável, inclusivo e assentado na mutualidade.

\section{BASES BIOLÓGICAS E PSICOSSOCIAIS DA COOPERAÇÃO}

As bases da cooperação são biológicas e sociais, encontram-se na interação entre a biologia e a vida social ao longo do processo de evolução. Suas manifestações mais remotas incluíram divisão voluntária de alimentos, cuidado de crianças, doentes e idosos, divisão de trabalho, partilha de informações, caça em grupo e guerra coletiva. A revolução agrícola, o surgimento do Estado e mercado, a revolução científica e tecnológica são fenômenos sociais que alteraram as formas de cooperação, mas sob as mesmas são identificáveis quatro bases bio-psicossociais inscritas na natureza humana.

\section{VÍNCULOS SOCIAIS}

Ao nascer, os humanos estão em condição extremamente frágil. Incapazes de prover seu alimento, locomoção e segurança, dependem em tudo dos pais e adultos. 0 vínculo mais fundamental da criança, o mais forte e imediato, é com a mãe e o pai (ou responsáveis). Da relação dinâmica entre os atributos psicológicos inatos, os primeiros vínculos e as relações do entorno dependem os vínculos duráveis e o desenvolvimento do cérebro e do corpo. 0 temperamento diferenciado entre os bebês é revelador da influência genética; as mudanças no temperamento durante a vida revelam a influência do meio.

Os vínculos sociais têm a ver com o ser humano na sua integralidade. Quem interage com o ambiente e com outros "eus" não é uma mente racional: é o organismo como um todo. Em O Erro de Descartes, Antonio 
Damásio (1996) apresenta substanciais evidências para a tese de que os nossos vínculos com os outros humanos e com a natureza tem base emotivo-racional. Emoções e sentimentos processam-se no cérebro e são componentes essenciais do ato de pensar. Para o bem e para o mal, emoções e sentimentos são condições da mente e a incapacidade emocional derivada de doenças ou lesões inviabiliza o planejamento e a tomada de decisões. As operações racionais dependem não de um único centro cerebral, mas de vários sistemas cerebrais concertados ao longo de muitos níveis de organização neuronal. 0 tronco cerebral é a parte estrutural mais antiga do cérebro, que remonta aos períodos mais distantes da nossa evolução, e cumpre funções básicas de sobrevivência (batimentos cardíacos, digestão, respiração), enquanto o córtex cumpre funções mais "avançadas" e recentes, relacionadas às representações dos sentidos, à linguagem, à razão abstrata. Regiões cerebrais de "alto nível" e de "baixo nível", dos córtices pré-frontais ao hipotálamo e o tronco cerebral, cooperam umas com as outras na feitura da razão. Em oposição ao dualismo cartesiano, Damásio sustenta que a mente é um produto do organismo (não apenas do cérebro) e que o organismo interage com o ambiente como um conjunto, não apenas como cérebro ou como corpo.

Para sermos mental e fisicamente saudáveis necessitamos de vínculos sociais significativos. A ausência de vínculos significativos constitui uma perigosa fonte de doenças: a solidão. Cacioppo e Patrick (2010) caracterizam a solidão como uma "dor social", que constitui um sintoma de que algo não vai bem. Assim como a dor física tem a função de alertar o indivíduo acerca de problemas físicos, a dor social tem a função de proteger o indivíduo dos perigos de ficar isolado. Ela é um alerta para que os humanos prestem atenção aos seus vínculos com os outros. A dor social não é uma metáfora: por meio de ressonância magnética verifica-se que a região do córtex cingulado dorsal anterior registra as reações emotivas à rejeição social, e essa região é a mesma que registra as reações emotivas à dor física. 0 nível de vulnerabilidade ao vínculo social, explicam os autores, varia de uma pessoa a outra. Alguns precisam de contatos sociais frequentes para se sentirem tranquilos e seguros, outros, menos frequentes, mas todos necessitam da convivência significativa com outros. Sua ausência leva à insegurança, inaptidão para reconhecer a 
perspectiva dos outros, desconfiança acerca dos outros e incapacidade de pensar com clareza; favorece problemas físicos como alteração da função cardiovascular, aumento do estresse, aceleramento do envelhecimento; está relacionada a abuso de álcool e drogas, bulimia nervosa, obesidade, ocorrência de divórcios, baixo desempenho laboral e suicídios.

A habilidade de autorregular nossa relação com o ambiente social é um dos principais requisitos da vida em sociedade, a qual é afetada por um medo opressivo - o terror de se sentir desamparado e perigosamente sozinho. A autorregulação só é possível mediante a corregulação, um movimento bi-direcional entre o indivíduo e o seu meio, de ondulações de ida e volta entre os indivíduos. A compreensão que emerge dos estudos da solidão, nas palavras de Cacioppo e Patrick (2010, p. 242), é que "quando nos sentimos isolados, estamos o tempo todo prontos para o combate" e que "quando estamos satisfeitos com nossos vínculos sociais, nos sentimos seguros", sensação que nos permite pensar de maneira mais criativa, experimentamos emoções positivas e nos sentimos encorajados à colaboração e à ajuda aos outros.

\section{NECESSIDADES BÁSICAS}

Conectados e naturalmente dependentes dos outros, nossas necessidades básicas são tanto de ordem física/material quanto de ordem social/ imaterial. A pirâmide de Abraham Maslow (2013) é uma das mais conhecidas formulações sobre as necessidades básicas, constituída por cinco níveis, cada qual sendo condição para o nível seguinte: 1 . Fisiológicas; 2. Segurança (abrigo, sustento financeiro); 3. Amor (afeto, pertencimento); 4. Estima (reconhecimento das capacidades pessoais); 5. Auto-realização (tornar-se o que o indivíduo pode ser).

Etzioni (1980) apresenta uma hierarquia de necessidades básicas parcialmente modificada: 1. Fisiológicas; 2. Afeto, amor; 3. Reconhecimento, aprovação; 4. Sentido de contexto, de coerência ou totalidade; 5. Satisfação repetida; 6. Sentido de estabilidade quanto às expectativas; 7. Adequação dos papeis às diferentes personalidades. 
Para Maslow e Etzioni, a fisiologia constitui o nível mais elementar das necessidades, mas a nossa condição de seres vinculados socialmente importa em necessidades propriamente sociais, que não vem "depois" das fisiológicas, mas estão imbricadas com as mesmas. Afeto, reconhecimento, sentido de contexto são necessidades próprias do convívio, mas mesmo as necessidades fisiológicas como beber e comer estão envoltas por ritos e significados sociais. A flexibilidade das necessidades é limitada; não são manipuláveis no longo prazo, apenas no curto prazo mediante formas "não-naturais", como a manipulação midiática e de lideranças carismáticas. No longo prazo, assegura Etzioni, a sociedade não pode ser boa nem mesmo estável sem responder às necessidades dos seus membros.

Esse entendimento sobre as necessidades básicas vem sendo respaldado pelos estudos sobre o sentimento de bem-estar e de satisfação com a própria vida. Um pressuposto aceito nessas pesquisas, segundo Richard Layard (2008, p. 254), é que "geralmente o que nos torna felizes é bom para nós e, portanto, ajudou a perpetuar a nossa espécie”. Levantamentos de opinião em vários países mostram que apenas uma parcela do bem-estar deve-se à renda e à capacidade de consumo, diz o autor, e, alcançada uma vida confortável, ganhar mais e consumir mais deixa de ser relevante. Investigações conduzidas por Tim Kasser (2002) corroboram esse raciocínio com evidências de que valores materialistas estão associados a baixos níveis de bem-estar, ao passo que vínculos interpessoais significativos, reconhecimento, confiança interpessoal e participação em organizações sociais são sempre importantes.

Prazer e dor são variáveis fundamentais na vida humana, mas a dimensão moral também é. A teoria da dupla motivação (ETZIONI, 2007) explica que o comportamento humano é orientado, por um lado, pela busca do prazer e a fuga da dor e, por outro, pelo senso de dever, de fazer o que se considera o certo a fazer. Essa concepção é corroborada por pesquisas sociológicas que mostram que muitas das ações humanas são contrárias ao prazer pessoal imediato, como atos altruístas de ajudar outros em situações de dificuldades, cuidar de pessoas doentes ou assumir causas que provocam instabilidade nas relações do círculo familiar ou de amizades. 


\section{EMPATIA}

Empatia designa a capacidade de colocar-se no lugar do outro, de sentir e enxergar as coisas sob o prisma do outro. A palavra originou-se da tradução do termo alemão Einfühlung ("sentir dentro") para o inglês empathy, derivado do grego empatheia (paixão).

Trata-se de uma capacidade inata aos seres humanos, relacionada às estruturas profundas da mente. Sua base é emocional, pré-racional, mas está envolta pela racionalidade e se realiza sob influência do ambiente social. Frans de Waal, em A Era da Empatia, de 2009, associa a empatia a dois fenômenos emocionais: o mimetismo e o contágio emocional. 0 mimetismo consiste na sincronização automática frente a expressões afetivas, a vocalizações, a posturas e a movimentos de outra pessoa: tendemos a rir em face do riso alheio, bocejar diante do bocejo, entrar no embalo dos movimentos de dança. 0 contágio emocional é o envolvimento instintivo com emoções alheias: crianças pequenas começam a chorar quando escutam outra criança chorar; crianças e adultos reproduzem imediatamente emoções identificadas em expressões faciais de angústia, tristeza ou alegria de outros. "As conexões corporais vêm primeiro - a racionalização vem depois", diz Waal (2010, p. 108). Essa faculdade de estabelecer conexões diretas com "outros eus" existe também em primatas, elefantes e outros animais, e remonta a um período evolutivo muito antigo.

Afirmar que a raiz da empatia é emocional confronta a longa tradição filosófica racionalista-cartesiana, segundo a qual as interações entre pessoas se dão com base em nossas faculdades racionais. A descoberta dos neurônios-espelho veio a respaldar a nova abordagem. Giácomo Rizzolatti, da Universidade de Parma, em experimentos com macacos, utilizou eletrodos para mapear as reações cerebrais diante do manejo de objetos. Para sua surpresa, constatou que alguns neurônios da área F5, localizada no lobo frontal, eram ativados não só quando o animal realizava um movimento como apanhar uma uva ou amendoim, mas também quando o animal observava um outro indivíduo (macaco ou ser humano) realizando a mesma tarefa. Ou seja, esses neurônios "espelhavam" o que acontecia no cérebro de outro indivíduo. Humanos podem "compreender 
emoções através de um mecanismo de mapeamento direto envolvendo partes do cérebro que geram respostas motoras viscerais". Esse mecanismo de entendimento de emoções não explica toda cognição social, mas fornece uma base neuronal funcional para "parte das relações interpessoais sobre a qual estão construídos comportamentos sociais mais complexos. Pode ser o substrato que nos permite empatizar com outros, por exemplo", resumem Rizzolatti, Fogassi e Galese (2006, p. 60). Esses neurônios permitem tanto a compreensão direta das ações dos outros como a identificação das intenções, estando associados a comportamentos como imitação, aprendizado de habilidades e leitura da intenção em outros, e sua disfunção pode estar envolvida com a gênese do autismo.

As descobertas acerca da empatia e dos neurônios-espelho comprovam que nossa espécie possui uma base biológica favorável ao comportamento colaborativo: a cooperação se beneficia decisivamente da compreensão dos sentimentos, intenções e concepções dos outros. A automaticidade da empatia a que se referem os pesquisadores diz respeito à velocidade da reação, mas não significa que esteja fora de controle. A empatia é controlada socialmente, por fatores ligados à rede social à qual pertencemos. Essa rede condiciona nossa identificação com os outros. A identificação abre a porta para a empatia; sua falta pode bloqueá-la. Em diferentes espécies animais, pertencer à "tribo" é critério para o comportamento benevolente; ser "de fora" pode bloquear a ajuda ou mesmo levar à contra-empatia. (WAAL, 2010)

Os fenômenos empáticos decorrem de um impulso emocional-corporal, mas se realizam segundo as condições da nossa natureza emocional-racional. Estabelecida a conexão emocional, as respostas podem ser emoções sociais de simpatia (sentimento de afinidade com o bem-estar de outro), preocupação empática (emoção suscitada por alguém necessitado e em prol do mesmo) e compaixão (sentimento de pesar com o sofrimento alheio), as quais estão na raiz de comportamentos de solidariedade. Ricard (2015, p. 68) apresenta um exemplo didático: numa situação em que sinto fortemente a emoção do outro, meu coração pode acelerar e as pupilas podem contrair sem que eu me dê conta dessas reações; é a partir do momento em que penso "estou ansioso porque ele 
está ansioso" é que passo do contágio emocional à empatia, à ressonância afetiva consciente.

Psicólogos distinguem duas dimensões empáticas: a cognitiva e a afetiva. A empatia afetiva envolve a habilidade de compartilhar ou espelhar as emoções de outrem. A empatia cognitiva, a de considerar o ponto de vista do outro, de adotar a sua perspectiva. Roman Krznaric (2015, p. 41) unifica essas dimensões na sua definição: "empatia envolve pôr-se na pele de outra pessoa, ganhando uma compreensão de seus sentimentos (o aspecto afetivo) e perspectivas (o aspecto cognitivo), e usar essa compreensão para guiar nossas ações". Ambas as dimensões fazem parte do repertório mental da espécie humana, desenvolvido ao longo de milhões de anos para dar conta das complexas interações sociais das sociedades atuais.

\section{PREDISPOSIÇÃO ALTRUÍSTA}

O altruísmo (do latim alter $=$ outro) é geralmente associado a condutas heroicas e de auto-sacrifício, mas cientificamente vem sendo compreendido num sentido mais abrangente: são altruístas as ações cuja motivação é aumentar o bem-estar do outro. Uma ação não deixa de ser altruísta se ela beneficia quem a pratica, mas o bem do outro deve ser a finalidade da ação; em havendo, o benefício próprio é consequência secundária. 0 termo altruísmo está associado a diversas inclinações pró-sociais: "generosidade, benevolência, perdão, voluntariado, amor irrestrito, virtude, filantropia e amor altruísta são termos usados para indicar específicas manifestações dessa orientação generalizada". (JEFFRIES, 2014)

Os comportamentos altruístas não são raros, pelo contrário, são absolutamente comuns em todas as sociedades. Daniel Batson apresenta em O Altruísmo em Humanos, de 2011, resultados de experimentos laboratoriais que comprovam que o altruísmo é um fenômeno cotidiano: no dia a dia, parte significativa das ações das pessoas comuns são movidas pela intenção de aumentar o bem-estar dos outros. 0 autor testou a hipótese empatia-altruísmo: o altruísmo deriva da preocupação empática 
com outra pessoa, necessitada de ajuda. E as evidências auferidas em experimentos laboratoriais mostram que as pessoas são, sim, capazes de pensar no bem-estar alheio antes do bem-estar próprio. Não se trata de retomar a tese da benevolência natural e sim compreender que em nossa mente coexistem motivações egoístas e altruístas: as primeiras visam o próprio bem-estar, as últimas, o bem-estar alheio. Muitas ações humanas enquadram-se neste último caso, e é possível que seu substrato genético esteja no ato parental de nutrição da prole. As implicações da hipótese empatia-altruísmo são importantes: a empatia está associada à "ajuda cada vez mais sensível aos necessitados, menos agressão, maior cooperação em situações competitivas, atitudes melhoradas e mais ação em favor de grupos estigmatizados e relacionamentos mais positivos e próximos". (BATSON, 2011, p. 232)

Ricard (2015), biólogo e monge budista, sistematiza uma teoria do altruísmo com base em aportes científicos e do pensamento budista. Sob o pressuposto budista de que todos buscamos fugir do sofrimento e visamos a nossa realização pessoal, considera que o egoísmo, nascido do exacerbado sentimento da importância de si mesmo, é fonte de tormenta e infelicidade e está em contradição com a realidade, por apoiar-se no falso postulado de que os indivíduos são entidades isoladas, independentes umas das outras. Tudo é interdependente e por compreender essa interdependência o altruísta consegue se colocar no lugar do outro, respeitá-lo, querer sua felicidade. Essa atitude combina com o processo de evolução dos animais sociais que somos: amor, afeição e cuidado com os outros são vitais para a sobrevivência da espécie. É o altruísmo que coaduna-se com o fluxo evolutivo, não o egoísmo.

Os estudos sobre comportamentos empáticos em crianças pequenas respaldam a tese altruísta. Contrariamente à concepção de Freud (para quem a criança é fortemente egoísta) e bem antes do que Piaget previra (os comportamentos empáticos só começariam a se manifestar a partir da idade escolar), Michael Tomasello e Felix Warneken (2006) trazem evidências de que muito cedo, já aos 18 meses, crianças são capazes de ajudar espontaneamente os outros. Os comportamentos cooperativos infantis são precoces, espontâneos (não dependem de pressão externa), manifestam-se na mesma idade em culturas diferentes e são observáveis 
também em filhotes de grandes macacos, o que reforça a interpretação de que a cooperação remonta ao ancestral comum aos humanos e chimpanzés (seis milhões de anos).

Nessa linha, o desenvolvimento das aptidões cooperativas derivadas da empatia infantil depende da influência cultural, do processo de socialização e do ambiente social. Crianças educadas no seio de culturas coletivistas, nas quais a ênfase é colocada no bem-estar do grupo e na vida comunitária, comportam-se com mais altruísmo que aquelas de culturas individualistas. No extremo oposto, o comportamento agressivo e egoísta cresce em ambientes de forte pressão, como fomes prolongadas e ameaças de morte.

0 uso de meios formativos adequados pode fortalecer o altruísmo e a cooperação. Pesquisas acerca dos efeitos da meditação revelam a neuroplasticidade cerebral, a contínua evolução do cérebro face a situações novas. 0 cérebro adulto produz constantemente novos neurônios, reforça ou diminui a atividade de neurônios existentes e inclusive atribui novas funções a áreas que habitualmente desempenham outras funções. Neurocientistas comprovaram que é possível treinar a mente para a prática do altruísmo, com exercícios como a meditação. Ricard (2015, cap. 21) relata que pesquisas com mais de uma centena de praticantes de meditação, em cerca de 20 universidades, com uso de técnicas como eletroencefalograma e ressonância magnética funcional, revelaram que meditantes apresentam maior atividade cerebral de áreas associadas à compaixão e maior sincronização das oscilações das ondas cerebrais nas frequências gama, associadas à conectividade, em relação a não-meditantes. E que após algumas semanas de meditação comprovou-se aumento de emoções positivas como alegria, esperança, gratidão, entusiasmo e grau de satisfação diante da existência. Pesquisas em laboratórios de alto nível, segundo Ricard, continuam coletando dados que comprovam que a meditação desencadeia mudanças funcionais e modificações na estrutura do cérebro, favorecendo comportamentos pró-sociais e fortalecendo a saúde mental e física.

É amplamente aceito nos meios científicos a ideia de que o altruísmo recíproco (mutualidade) é prevalecente, mas também, como ressalvam Bowles e Gintis (2013, p.199), que o altruísmo genuíno explica parte im- 
portante do comportamento cooperativo e que é uma "exigência essencial da vida econômica e social".

\section{VARIADAS FORMAS DE COOPERAÇÃO NAS DIFERENTES ESFERAS SOCIAIS}

Vínculos sociais, necessidades básicas, empatia e predisposição altruísta são o alicerce sobre o qual se desenvolveram as diversas formas de cooperação entre os humanos. A ajuda mútua mostrou-se altamente benéfica para seus membros, sendo acompanhada e fortalecida por preferências sociais, habilidades linguísticas e cognitivas. Fonte de prazer e de satisfação, a cooperação passou a se expressar em variados rituais e a fazer parte dos jogos políticos nas diferentes sociedades. (SENNETT, 2012)

Os comportamentos colaborativos são sustentados por normas, preferências e emoções sociais e pela ética da reciprocidade, que instituiu mecanismos de premiação aos cooperadores e de punição aos free riders (caroneiros, parasitas). As emoções básicas (dor, prazer, raiva, medo, surpresa e descontentamento) e as emoções sociais (amor, culpa, vergonha, constrangimento, orgulho, inveja e ciúme) constituíram o substrato psicológico da ajuda mútua e reduziram o custo da punição às transgressões, transmitidas de geração a geração.

A cooperação não dispensa regras e punições. Experimentos conduzidos pelo economista Ernst Fehr em diversos países mostram que $60 \%$ a $70 \%$ das pessoas confiam umas nas outras e colaboram espontaneamente, enquanto $30 \%$ tendem a não cooperar. Nos testes envolvendo distribuição de dinheiro, o comportamento egoísta da minoria mostrou-se, todavia, um fator corrosivo, minando a confiança dos cooperantes. Com a introdução de "penalidades altruístas" aplicadas aos egoístas a cooperação se estabilizou próxima dos 100\%, indicando que a maioria das pessoas não tolera o comportamento parasita e que os próprios individualistas acabam por perceber as vantagens da reciprocidade quando há regras claras. (FEHR; GÄCHTER, 2000)

Vinculado à estrutura biológica herdada dos antepassados, o comportamento colaborativo de cada indivíduo é condicionado social e his- 
toricamente. Cultura, instituições e organizações que formam o sistema político e socioeconômico incidem sobre a intensidade e as múltiplas formas de cooperação nas diferentes esferas sociais - Estado, comunidade e mercado.

Famílias e comunidades são os ambientes da reciprocidade direta, caracterizados pelo afeto, calor humano, segurança e apoio para vencer grande parte das dificuldades da vida, como situações de mudança de residência, de desemprego, de dificuldades financeiras, de desempenho escolar, de doenças e drogadição. A fragilização de tais redes é particularmente aguda em tempos de crise econômica e nos ambientes de pobreza e marginalização, quando à ausência de políticas públicas soma-se a falta de amparo dos familiares, amigos, vizinhos, escola ou igreja. (PUTNAM, 2015)

No último século, Estado e mercado absorveram parte significativa das funções econômicas, normativas e até mesmo emocionais da família e comunidade, com severas consequências. "Milhões de anos de evolução nos projetaram para viver e pensar como membros de uma comunidade; em apenas dois séculos, nos tornamos indivíduos alienados", diagnostica Harari (2017, p. 371). Mas, as comunidades não pereceram, elas se transformaram e continuam cumprindo funções relevantes, e mesmo quando as políticas públicas estão bem estruturadas, essas redes são indispensáveis para o bem-estar e a felicidade individual.

0 terceiro setor - conjunto das organizações da sociedade civil ${ }^{3}-$ é um importante espaço de mutualidade voltado ao interesse público. Cronologicamente, o "terceiro" setor é o primeiro setor: as organizações da sociedade civil dos dias de hoje atualizam o espírito de cooperação e autogestão do associativismo de outras eras. No Brasil, destacam-se as entidades comunitárias (universidades, escolas, hospitais, rádios e TVs, bancos, associações, fundações), cooperativas, entidades mutualistas, organizações não governamentais e organizações da economia solidária. 0 terceiro setor abriga variadas formas de voluntariado e filantropia, mas cabe reconhecê-lo mais como espaço de mutualidade do que de filantropia. (ETZIONI, 2001)

O Estado (que se sobressai pelo caráter coercitivo e hierárquico) também é espaço de cooperação. Leis e institutos de fomento à participação popular e à deliberação pública, como audiências públicas, orça- 
mento participativo, conselhos de políticas e outras formas dialógicas de governança, são mecanismos que robustecem o senso de empoderamento e de responsabilidade dos cidadãos. A intersetorialidade e a cooperação entre entes federativos são formas relevantes de práticas colaborativas.

O mercado também funciona melhor onde há confiança e cooperação. A confiança entre os agentes econômicos reduz os custos de controles e da judicialização, facilita os intercâmbios e o comércio. A colaboração entre empresas e o seu compromisso com questões públicas azeitam as engrenagens do mercado. Nas empresas, a produtividade aumenta mais quando há estímulo ao trabalho de equipe, em lugar da competitividade individual. Benkler (2011) assinala que o pensamento econômico ocidental incorporou a cooperação como fator de produtividade a partir da década de 1980 face ao sucesso da Toyota, cujo modelo de gestão enfatiza o trabalho em equipe e engajamento ativo dos trabalhadores ao invés dos mecanismos de controle, punição, incentivo e premiação.

Cooperação não é sinônimo de inclusão e nem sempre converge ao bem comum. Grande parte da cooperação serviu historicamente ao interesse de poucos em detrimento de muitos. Tribalismo, competição e conflitos são fenômenos que acompanham as práticas colaborativas.

O tribalismo, segundo os biólogos, constitui um dos universais da natureza humana. As pessoas precisam de uma tribo, que lhe dá um nome e um sentido identitário num mundo caótico. Wilson (2013, cap. 7) diz que o mundo moderno é um sistema de tribos entrelaçadas, em que as pessoas saboreiam e buscam a convivência com pessoas afins. 0 tribalismo entrecruza-se com a competição e a conflituosidade: guerras, enfrentamentos étnicos e litigiosidade põe em lados opostos multidões que cooperam para se combater. E no terreno econômico, a competição entre corporações rege em grande parte a dinâmica capitalista.

Tribalismo, conflito e competição não são o oposto de cooperação; estão, na verdade, interrelacionados. Segundo a teoria do conflito desenvolvida pelo sociólogo Georg Simmel, cooperação, conflito e competição são impulsos que convivem na vida social. 0 antagonismo deve ser lido à luz da dialética dos contrários entre unidade e diferença, harmonia e dissonância, associação e luta, simpatia e antipatia. A hostilidade é uma das “energias primárias do homem", uma pulsão “simétrica à necessidade 
de simpatia". (SIMMEL, 2013, p. 30/31) A competição é uma forma de conflito, uma "luta indireta", que visa vencer o adversário sem prejudicá-lo diretamente. Quando não excessivamente violenta a competição tem ampla aceitação social. Vinculada ao processo de descentralização que substituiu a solidariedade estreita e ingênua das organizações primitivas, é um mecanismo de interação com capacidade de síntese e força socializadora. Quanto mais o liberalismo penetrou o tecido social, mais as relações estão à mercê do equilíbrio instável que é próprio da competição. Simmel (2013, p. 83) considera que os motivos de término de um conflito são o desejo de paz, o esgotamento de forças e o surgimento de um interesse superior dirigido a outro objeto. Compromisso e reconciliação são modos fundamentais de solução de conflitos.

Ambientes permeados por conflitos não excluem a competição. 0 cientista político Robert Axelrod, em A Evolução da Cooperação, de 1984, mostra que mesmo sob o viés da abordagem estratégica (alicerçada na premissa do egoísmo) o comportamento cooperativo é vantajoso para indivíduos que buscam seu próprio interesse. Utilizando a teoria dos jogos, o autor promoveu um torneio de computador em que teóricos foram convidados a enviar suas estratégias favoritas para o jogo "dilema do prisioneiro". Para sua surpresa, a estratégia vencedora em diversas rodadas foi a mais simples de todas: denominada Olho por Olho (Tit for Tat), ela consiste em adotar a cooperação na primeira jogada e depois fazer o mesmo que o oponente fez na jogada anterior. Predisposição inicial para a cooperação seguida de ações recíprocas. Axelrod destaca que a força dessa estratégia se manifesta em condições de iteratividade, ou seja, quando há perspectiva de reencontros futuros entre os competidores. Seu argumento central é que "a evolução da cooperação requer que indivíduos tenham chances suficientemente grandes de se encontrar novamente para que tenham um interesse nas relações futuras". (AXELROD, 2010, p. 19) 


\section{COOPERAÇÃO PÚBLICA E PARADIGMA COLABORATIVO NAS POLÍTICAS PÚBLICAS}

A índole cooperativa da nossa espécie não prosperou até agora em direção ao interesse geral da humanidade. A cooperação existente nas diferentes sociedades é majoritariamente "fechada", aprisionada pelos interesses tribais e de classe. Construir a cooperação pública "aberta" exige a transformação das estruturas econômicas, das engrenagens políticas e da cultura de consumo associada ao capitalismo. Insustentável ambientalmente, o sistema capitalista perpetua a lógica da desigualdade social, que resulta em danos profundos à saúde física e mental, à confiança interpessoal, denigre a condição da mulher, agudiza o êxito escolar, a violência, o índice de encarceramento e a mortalidade infantil. A desigualdade é o maior dos males atuais e um obstáculo à reciprocidade generalizada. (WILKINSON; PICKETT, 2010)

O economista Jonathan Boswell (1994) argumenta que o exame das políticas econômicas oferece interessantes exemplos de cooperação pública, de ação articulada e convergente entre entes sociais, privados e estatais em vista de fins públicos, ou seja, "processos nos quais empresa, sindicato e outras organizações setoriais colaboram livremente entre si e com outros grupos ou governo em favor de interesses públicos”. A cooperação pública compreende as formas de ação coletiva em que os interesses de grupo, classe ou país são compatíveis com o interesse geral das gerações humanas presentes e futuras.

A superação do paradigma da competição (predominante no capitalismo) pelo paradigma colaborativo nas políticas públicas é parte do processo de transformação social, econômica e política. Entre diversos aspectos, o novo paradigma requer a revisão das fronteiras artificiais e rígidas entre Estado, sociedade civil e mercado, a centralização das decisões, a fragmentação das ações, as duplicidades. Na medida em que sempre envolvem e afetam múltiplos sujeitos, a competição limita severamente a eficácia e eficiência das políticas. A complementaridade e sinergia entre agentes públicos, privados e do terceiro setor já vêm sendo reconhecida em inúmeros estudos como requisito para a qualidade das políticas públicas, mas em grande parte dos casos os estudos 
aceitam implicitamente a dicotomia público/privado que está na raiz da fragmentação.

O paradigma colaborativo, mais do que um norte para as políticas públicas, é um novo fundamento da vida social. Fundamentado na índole natural à solidariedade, preconiza que a cooperação aberta, pública, conduz às melhores resposta aos problemas comuns. (ETZIONI, 2001) $\mathrm{Na}$ economia, traduz-se nas iniciativas da economia solidária, economia social, do comparilhamento ou do cuidado. Na política, nas experiências de democracia participativa e deliberativa. No âmbito sócio-cultural, traduz-se em políticas de afirmação dos direitos humanos, de reconhecimento da diversidade e de inclusão social, correspondendo a estilos de vida solidários.

Para muitos, esse paradigma é algo distante e improvável, por não perceber que há transformações profundas em curso que podem ser tomadas como anúncio e prenúncio. 0 politólogo Ronald Ingelhart mostra que há décadas vem acontecendo uma ampla mudança intergeracional de valores - passagem dos valores materialistas para valores pós-materialistas -, proeminente especialmente em jovens de países desenvolvidos e secularizados. Livres das preocupações econômicas vinculadas à sobrevivência, esses jovens desenvolvem valores pós-materialistas de auto-expressão, de atenção à qualidade de vida, de proteção ambiental, de tolerância à diversidade, de participação nas decisões econômicas e políticas, de tolerância a estrangeiros e de reivindicações de gênero. (INGLEHART; WELZEL, 2009) Grande parte dessas tendências são compatíveis com ambientes favoráveis à empatia e à cooperação.

Rifkin (2010) assegura que a terceira revolução industrial inaugura condições objetivas para a civilização empática. Argumenta que o desenvolvimento tecnológico está associado a um amplo conjunto de manifestações de cunho empático no campo do trabalho, da cultura, das artes, tendo por base a imensa a facilidade de conexões sociais possibilitada pela internet, meios de comunicação e meios de transporte. A internet das coisas é a plataforma para um novo paradigma econômico, com a passagem da economia capitalista de mercado (com o predomínio do trabalho individualizado, da propriedade privada e da posse dos bens) para a economia do compartilhamento (de trabalho colaborativo, governança dos 
bens comuns e acesso aos bens). As evidências da nova economia estão em toda parte: milhões de pessoas produzem e disseminam a própria informação a um custo quase zero; em toda parte prossumidores geram a energia que consomem; a educação online quase gratuita alastra-se; surgem a cada ano formas compartilhadas de geração e novos usos de bens sociais (Linux, Wikipedia, meios de compartilhamento de música, de informações, aluguel de casas, bicicletas, carros, terrenos urbanos). Rifkin (2016, p. 14) faz um prognóstico audacioso: “a economia de compartilhamento de bens comuns colaborativos está em ascensão e, em 2050, provavelmente terá se estabelecido como principal árbitro da vida econômica na maior parte do mundo". Embora tal previsão soe excessivamente otimista, a relevância do argumento está em identificar variadas tendências empáticas e cooperativas em meio ao clima aparentemente caótico da globalização. A empatia, diz Rifkin, não é a cura de todos os males e sim uma oportunidade para unir a espécie humana, que só se confirmará se formos capazes de superar os extraordinários obstáculos à nova civilização, como as forças entrópicas que estão na raiz do desenvolvimento econômico capitalista. Vivemos hoje os impasses entre empatia e entropia, consciência biosférica e colapso planetário, economia de mercado e economia do compartilhamento.

Em termos de prospecção do futuro, o paradigma colaborativo encontra uma inspiradora expressão na noção comunitarista da cultura comunitária pós-moderna, exposta por Etzioni (2015; 2017). O bem-estar e a felicidade estão profundamente vinculados ao convívio interpessoal, à vida comunitária. As grandes fontes do bem-estar "custam barato": música, arte, lazer, convívio, trabalho coletivo, cooperação, atividades espirituais, tudo isso requer poucos recursos naturais e é compatível com as tendências de baixo crescimento econômico do século XXI. Dedicar tempo aos filhos, familiares, vizinhos e amigos, envolver-se em clubes e organizações, engajar-se na ação coletiva, participar das decisões públicas são ações que exigem tempo e energias sociais, mas têm pouco impacto ambiental e custo financeiro. Há, por isso, uma surpreendente convergência entre justiça social, vida comunitária e sustentabilidade. 


\section{CONCLUSÃO}

Evidências científicas de vários campos do conhecimento sustentam a asserção aqui exposta de que vínculos sociais, necessidades básicas, empatia e predisposição altruísta constituem bases bio-psicossociais da cooperação humana. Essas bases estão inscritas na natureza humana e foram fundamentais para que os humanos ascendessem à condição de supremacia que ocupam hoje no planeta. 0 novo evolucionismo que se desenvolveu no século XX a partir de Kropotkin atesta que somos uma espécie cooperativa, não na perspectiva rousseauniana da benevolência inata e, sim, na da condição de seres que vivem a tensão entre impulsos egoístas e de ajuda mútua.

Apesar das influências contrárias nas sociedades de classe e dos ambientes de conflito, a cooperação continua sendo um fato cotidiano em todas as sociedades. Essa constatação e o conjunto das evidências científicas destacadas ao longo do texto permitem algumas conclusões de grande alcance político.

A primeira: a teoria da cooperação avaliza a tese comunitarista de que a vida social é melhor explicada com base em três esferas sociais: distinta do Estado (esfera estatal) e do mercado (esfera privada), a comunidade (esfera comunal, terceiro setor) abrange o amplo leque de ações mutualistas e altruístas em prol do atendimento de necessidades comuns. A segunda: o terceiro setor não é propriamente uma novidade histórica: ele está ancorado na longa trajetória histórica da ajuda mútua característica da nossa espécie. A terceira; estatização e privatização não são os únicos caminhos para resolver problemas públicos ou gerir bens comuns: em muitos casos a melhor solução pode ser a proporcionada pela ação comunitária. A quarta: as bases bio-psicossociais da cooperação constituem condições favoráveis mas não suficientes para tornar hegemônico o paradigma colaborativo em políticas públicas: a luta política e a correlação de forças são determinantes para que o ideário da colaboração pública se imponha ou não sobre o atual viés competitivo.

O futuro está em aberto. As barreiras que se opõem ao paradigma colaborativo não são naturais: são culturais e institucionais. Fossem biológicas (genéticas) seriam intransponíveis no horizonte histórico que 
descortinamos hoje, sendo remetidas a milênios distantes. Sendo culturais e institucionais, estão no âmbito da liberdade humana (limitada) e podem ser modificadas num futuro próximo. Por isso, não é pequeno o dano que as ciências provocam quando difundem a noção de que somos seres egoístas por natureza e é grande o benefício que trazem ao evidenciar nossa índole colaborativa.

\section{NOTAS}

1 Este artigo é um dos resultados do pós-doutorado realizado em 2016 na The George Washington University, Washington DC, EUA. 0 autor agradece o apoio da CAPES, pela concessão de bolsa do Programa de Estágio Sênior (Processo BEX 5731/15-1), e à Universidade de Santa Cruz do Sul, pelo suporte proporcionado mediante o Programa de Apoio a Estágio Pós-Doutoral.

2 Na definição do biólogo Edward Wilson (2013, p. 234), "a natureza humana são as regularidades herdadas do desenvolvimento mental comuns à nossa espécie. São as 'regras epigenéticas' que evoluíram pela interação da evolução genética e cultural que ocorreu por um longo período na pré-história profunda. Essas regras são os vieses genéticos na forma como nossos sentidos percebem o mundo, a codificação simbólica pela qual representamos o mundo, as opções que automaticamente abrimos para nós e as reações que achamos mais fáceis e recompensadoras."

30 terceiro setor é frequentemente conceituado como conjunto das organizações não governamentais ou como conjunto das entidades sem fins lucrativos. Esse conceito é restritivo, pois não abarca um importante leque de organizações criadas e mantidas pela sociedade civil, com funções públicas não estatais. A teoria comunitarista de Amitai Etzioni proporciona suporte teórico ao conceito de terceiro setor como conjunto das organizações da sociedade civil, distinto do setor público (Estado) e do setor privado (mercado). Em todos os países, o terceiro setor é um conjunto heterogêneo, em que apenas parcela de suas entidades está assentada em valores compatíveis com a democracia inclusiva e a sustentabilidade socioambiental. (SCHMIDT, 2017).

\section{REFERÊNCIAS}

AXELROD, Robert. A evolução da cooperação. São Paulo: Leopardo, 2010.

BATSON, Daniel. Altruism in humans. New York: Oxford University Press, 2011.

BENKLER, Yochai. The penguin and the Leviathan: how cooperation triumphs over self-interest. New York: Crown Business, 2011.

BENTHAM, Jeremy. Uma introdução aos princípios da moral e da legislação. São Paulo: Abril Cultural, 1984.

BOBBIO, Norberto. Thomas Hobbes. Rio de Janeiro: Campus, 1991. 
BOSWELL, Jonathan. Community and the economy: the theory of public cooperation. London: Routledge, 1994.

BOWLES, Samuel; GINTIS, Herbert. A cooperative species: human reciprocity and its evolution. Princeton e Oxford: Princeton University Press, 2013.

CACIOPPO, John; PATRICK, William. Solidão: a natureza humana e a necessidade de vínculos sociais. Rio de Janeiro, São Paulo: Record, 2010.

CAPRA, Fritjof. As conexões ocultas: ciência para uma vida sustentável. 11ª̣ ed. São Paulo: Cultrix, 2009.

DAMÁSIO, António R. 0 erro de Descartes: emoção, razão e o cérebro humano. São Paulo: Companhia das Letras, 1996.

DARWIN, Charles. A origem das espécies. Leça da Palmeira: Planeta Vivo, 2009.

DOWNS, Anthony. Uma teoria econômica da democracia. São Paulo: EDUSP, 1999.

ETZIONI, Amitai. Social justice in the post-affluent society. Theory in Action, v. 10, n. 1, p. 1-6, Jan 2017.

ETZIONI, Amitai. The new normal: finding a balance between individual rights and the common good. New Brunswick: Transaction Publishers, 2015.

ETZIONI, Amitai. La dimensión moral: hacia una nueva economia. Madrid: Astor Juvenil Palabra, 2007.

ETZIONI, Amitai. La tercera vía hacia una buena sociedad: propuestas desde el comunitarismo. Madrid: Trotta, 2001.

ETZIONI, Amitai. La sociedad activa: una teoría de los procesos societales y políticos. Madrid: Aguilar, 1980.

FRANCISCO (Papa). Laudato Si': sobre o cuidado da casa comum. Brasília: Edições CNBB, 2015. 
FEHR, Ernst; GÄCHTER, Simon. Cooperation and punishment in public goods experiments. The American Economic Review, v. 90, n. 4, p. 980-994, set 2000.

HARARI, Yuval N. Sapiens: uma breve história da humanidade. 19a ed. Porto Alegre: L\&PM, 2017.

HOBBES, Thomas. Leviatã ou matéria, forma e poder de um estado eclesiástico e civil. Os Pensadores. São Paulo: Nova Cultural, 1997.

INGLEHART, Ronald; WELZEL, Christian. Modernização, mudança cultural e democracia: a sequência do desenvolvimento humano. São Paulo: Francis, 2009.

JEFFRIES, Vincent (ed.). The Palgrave handbook of altruism, morality, and social solidarity. New York: Palgrave Macmillan, 2014.

KRZNARIC, Roman. 0 poder da empatia: a arte de se colocar no lugar do outro para transformar o mundo. Rio de Janeiro: Zahar, 2015.

KROPOTKIN, Piotr. Ajuda mútua: um fator de evolução. São Sebastião: A Senhora Editora, 2009.

LAYARD, Richard. Felicidade: lições de uma nova ciência, Rio de Janeiro: Best Seller, 2008.

KASSER, Tim. The high price of materialism. Cambridge, Masachussets: The MIT Press, 2002.

MASLOW, Abraham. A theory of human motivation. In: DOHERTY, D.; ETZIONI, A. Voluntary simplicity: responding to consumer culture. Lanham: Rowman \& Littlefield Publishers, Inc, 2013, p. 29-40.

MARX, Karl. 0 capital: crítica da economia política. São Paulo: Abril Cultural, 1983.

MARX, Karl. Manuscritos econômico-filosóficos e outros textos escolhidos. Coleção Os Pensadores. São Paulo: Abril Cultural, 1978.

NOWAK, Michel; HIGHFIELD, Roger. Supercooperators: altruism, evolution and why wee need eacho other to succeed. New York: Free Press, 2011. 
OSTROM, Elinor. El gobierno de los bienes comunes: la evolución de las acciones de acción coletiva. México: Fondo de Cultura Económica, 2011.

PINKER, Steven. Os anjos bons da nossa natureza: por que a violência diminuiu. São Paulo: Cia das Letras, 2013.

PUTNAM, Robert. Our kids: the American dream in crisis. New York: Simon \& Schuster, 2015.

PUTNAM, Robert. Comunidade e democracia: a experiência da Itália moderna. Rio de Janeiro, Fundação Getúlio Vargas, 1996.

RICARD, Matthieu. A revolução do altruísmo. São Paulo: Palas Athena, 2015.

RIFKIN, Jeremy. Sociedade com custo marginal zero: a internet das coisas, os bens comuns colaborativos e o eclipse do capitalismo. São Paulo: M. Books, 2016.

RIFKIN, Jeremy. La civilización empática: la carrera a la consciencia global en un mundo in crisis. Madrid: Paidós, 2009.

RIZZOLATTI, Giacomo; FOGASSI, L.; GALLESE, V. Mirrors in the mind. 2006. Scientific American, p. 54-61, nov. 2006.

ROUSSEAU, Jean-Jacques. Do contrato social e outros textos. Coleção Os Pensadores. 3. ed. São Paulo: Abril Cultural, 1983.

SCHMIDT, João P. Universidades comunitárias e terceiro setor: fundamentos comunitaristas da cooperação em políticas públicas. Santa Cruz do Sul: Edunisc, 2017.

SENNETT, Richard. Juntos: os rituais, os prazeres e a política de cooperação. Rio de Janeiro, São Paulo: Record, 2012.

SIMMEL, Georg. El conflicto: sociología del antagonismo. 2. ed. Madrid: Sequitur, 2013.

SINGER, Tania; LAMM, Claus. The social neuroscience of empathy. The year in cognitive neuroscience 2009. Annals of the New York Academy of Sciences, p. 81-96, 2009. 
SMITH, Adam. A riqueza das nações: investigação sobre sua natureza e suas causas. Coleção Os Economistas. São Paulo: Nova Cultural e Círculo do Livro, 1996.

WAAL, Frans de. A era da empatia: lições da natureza para uma sociedade mais gentil. São Paulo: Cia das Letras, 2010.

WARNEKEN, Felix; TOMASELLO, Michael. Altruistic helping in human infants and young chimpanzees. Science, v. 311, p. 130-1303, mar. 2006.

WILKINSON, Richard; PICKETT, Kate. The spirit level: why greater equality makes societies stronger. New York: BLOOMSBURY PRESS, 2010.

WILSON, Edward. A conquista social da terra. São Paulo: Cia das Letras, 2013.

Recebido em: 11-10-2017

Aprovado em: 20-8-2018

\section{João Pedro Schmidt}

Pós-doutor pela George Washington University (Washington DC, EUA); doutor em Ciência Política pela Universidade Federal do Rio Grande do Sul; mestre em Filosofia pela Universidade Federal do Rio Grande do Sul; professor titular da Universidade de Santa Cruz do Sul. E-mail: jpedro@unisc.br Programa de Pós-Graduação em Direito da Universidade de Santa Cruz do Sul (UNISC)

Bloco 53 - Sala 5326. Av. Independência, 2293 - Bairro Universitário. Santa Cruz do Sul - RS. CEP: 96815-900 
